\title{
E-extension in Nepal: brief overview in Nepalese agriculture
}

\author{
Keshab Magar*
}

\begin{abstract}
E-extension is an approach to agricultural knowledge extension through electronic technologies where online platforms such as web sites, mobile applications and social media are used. Low cost and high effectiveness suggest substantial future possibilities. Nepal's rapid increase in internet usage provides the potential to employ eextension as a valuable mechanism in the prevailing system of agriculture extension, providing direct advantages to Nepalese farmers. Access to e-extension enables timely updates to newer technologies, information and enews, with better chances of broad discourse in Nepalese agriculture. This paper aims to document recent initiatives in current e-extension developments in Nepal. Constraints may arise from issues of user-friendliness, affordability and reliability. If promoted with innovation and considerations of actual access, e-extension can have multiple positive impacts on Nepalese agriculture in the near future.
\end{abstract}

For the Nepali translation, please see this link नेपाली अनुवाद को लागि, कृपया यो वेब लिंक हेर्नुहोस्

\section{Introduction}

Agricultural extension, the application of scientific research and new knowledge to agricultural practices through farmer education, has so far failed to produce the expected results in Nepal due to poor communication infrastructure, high extension costs in sustaining of extension coverage from government, and a high proportion of hill districts. Earlier extension approaches have been costly in both human resources and financial resources. ${ }^{[1]}$ The insufficient number of agriculture centers compared to number of municipalities raises questions as to the reach of extension efforts. Even for farmers in range of the existing extension systems, those systems may not pertain to their specific local needs. Furthermore, in most cases the prioritized groups have been only the lead or active farmers (who are rich in resources and can afford any inputs) and certain agro-enterprises. ${ }^{[2]}$ Improper coordination among governmental bodies and other bodies in agriculture extension has hampered the extension system, whose function

\footnotetext{
*Author correspondence: by online form Licensed under: CC-BY

Received 15-12-2019; accepted 08-09-2020
}

should have been the sharing of newer technologies with lower costs, thereby lowering the technical gap between research and extension. ${ }^{[3]}$

Extension systems must address the specific issues faced by farmers, ranging from crop and livestock production to pesticide use. Youth migration abroad has been an especially pressing problem. ${ }^{[4]}$ The challenge is to encourage them to remain in the country and to support them to continue in agriculture. An opportunity for the present extension system is therefore to educate and equip all involved agri-manpower with required agricultural knowledge. ${ }^{[5]}$ Dissemination of agriculture technological information via the traditional extension approaches has seemingly been insufficient. The chosen extension approach should provide agricultural information according to the needs of the target farmers with quick and reliable delivery. Such rapid access to agricultural information is possible through Information and Communication Technology (ICT), which relies on available physical communication equipment and infrastructure. Development and deployment of the basic ICT infrastructure requires cooperation of all stakeholders along with government. ${ }^{[6]}$ The goal of e-extension is to enhance existing agriculture extension methods. 
Afzal et al. (2016) define e-extension as present-time methods of extension services using electronic technologies and the Internet. ${ }^{[7]}$ It includes online web-portals, websites, social media, blogs, emails, and smart phones. E-extension acts as hub for farmers and other stakeholders to collaborate and combine their extension innovations. ${ }^{[8]}$

Information technology offers easy access to the latest information, reducing cost to both senders and receivers. Via ICT, market information is on hand to help in market decisions and to assist farmers in resolving technical difficulties. ${ }^{[7]}$ Agricultural development is already being uplifted in Nepal due to ICT with more involvement of marginal farmers. ${ }^{[9]}$ For instance, television as a form of mass communication has been able to reach and educate farmers and has played a valuable role in technology transfer. ${ }^{[10]}$ Similarly, mobile phone penetration in Nepal has grown enormously, with estimates of more than 41.1 million users in September 2019. ${ }^{[11]}$ Internet penetration in Nepal is about 79\%, with the country ranked second (after Bhutan) in social media penetration as of 2017. By the end of 2020, the government of Nepal intends to connect $90 \%$ of the total population to broadband services. ${ }^{[12]}$ This extended internet accessibility, if utilized conscientiously, can reduce the distance between extension agencies and farmers.

Nepal has already entered into the digital age. This surely needs to be reflected in the agro-advisory context of its agricultural extension system. This paper presents and lists e-extension initiatives by different organizations, covering all electronic and internet-based media which have the potential for, or have already demonstrated, constructive impacts in Nepalese extension. The paper concludes with a suggested model for e-extension in Nepal.

\section{Methods}

This report is based on a literature review of research articles, review papers, and books. Currently developed online sites, web pages and tools were also searched extensively. Google Play, national newspapers, organizational websites and social media sites were used to collect information on the development of mobile applications or other agriculture-related online resources.

\section{Results}

\section{Agricultural applications}

Mobile phones have been readily accepted for communication with experts and for peer-to-peer information sharing, with the aim of increasing economic gains. ${ }^{[13]}$ In addition to being widely used for real-time communication among farmers, there have been positive impacts from mobile-phone-mediated learning. ${ }^{[14]} \mathrm{Re}-$ maining challenges are more centered around acceptance among farmers, as a lack of operational skills can impede their involvement. ${ }^{[15]}$ Similarly, lack of confidence and awareness can cause adoption gaps. As with any ICT tool, acceptance has depended mainly on age and educational level. Despite these issues with acceptability, credibility and connectivity, there has been an observ ed increase in the knowledge of farmers. ${ }^{[16]}$

Table 1 | Mobile based applications with their features (continued next page)

\begin{tabular}{|c|c|c|c|c|}
\hline Name & General features & Developers & Installs & Weblink \\
\hline Smart Krishi & $\begin{array}{l}\text { Package of practices, agriculture } \\
\text { news, documents, e-books, } \\
\text { weather info, online queries to ex- } \\
\text { perts }\end{array}$ & Smart Krishi & 100,000 & $\begin{array}{l}\text { https://play.google.com/store/apps/de- } \\
\text { tails?id=com.sudip.smartkrishi }\end{array}$ \\
\hline Krishi Guru & $\begin{array}{l}\text { Crop advisory, weather info, pack- } \\
\text { age of practices, agriculture news, } \\
\text { consultation with agriculture ex- } \\
\text { perts, agri SMS, (some features } \\
\text { available offline) }\end{array}$ & ICT for Agri & 100,000 & $\begin{array}{l}\text { https://play.google.com/store/apps/de- } \\
\text { tails?id=com.ictfa.krishiguru }\end{array}$ \\
\hline NARC Krishi & Package of practices & $\begin{array}{l}\text { Nepal Agricultural } \\
\text { Research Council } \\
\text { (Offered by Dream- } \\
\text { Work Solution) }\end{array}$ & 10,000 & $\begin{array}{l}\text { https://play.google.com/store/apps/de- } \\
\text { tails?id=com.dws.narc.krishi }\end{array}$ \\
\hline $\begin{array}{l}\text { Livestock } \\
\text { Farming }\end{array}$ & $\begin{array}{l}\text { Information about livestock farm- } \\
\text { ing }\end{array}$ & $\begin{array}{l}\text { MiDas Education } \\
\text { Pvt. Ltd }\end{array}$ & 10,000 & $\begin{array}{l}\text { https://play.google.com/store/apps/de- } \\
\text { tails?id=com.midas.cattle }\end{array}$ \\
\hline
\end{tabular}




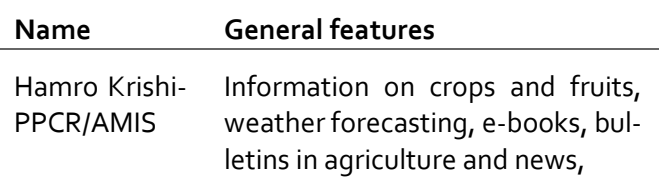

Krishi TV

Krishi

Kapurkot

Krishi Ghar

\begin{tabular}{|c|c|}
\hline $\begin{array}{l}\text { Aadhunik } \\
\text { Krishi }\end{array}$ & $\begin{array}{l}\text { App for supply and sale of modern } \\
\text { agricultural equipment }\end{array}$ \\
\hline $\begin{array}{l}\text { Tomato Ne- } \\
\text { pal }\end{array}$ & $\begin{array}{l}\text { Information on tomato cultivation, } \\
\text { especially business planning }\end{array}$ \\
\hline $\begin{array}{l}\text { Krishi Net- } \\
\text { work }\end{array}$ & Agricultural information and news \\
\hline Mobile Krishi & $\begin{array}{l}\text { Agriculture related information, } \\
\text { news, weather updates }\end{array}$ \\
\hline VCDC Nepal & $\begin{array}{l}\text { Materials for vegetable produc- } \\
\text { tion, official notices }\end{array}$ \\
\hline $\begin{array}{l}\text { Organic Ne- } \\
\text { pal }\end{array}$ & $\begin{array}{l}\text { Organic farming practices and its } \\
\text { commerciality }\end{array}$ \\
\hline Krishi Sewa & $\begin{array}{l}\text { Crop practices, expert consulta- } \\
\text { tion }\end{array}$ \\
\hline hankuta & Practices, news and notifications \\
\hline
\end{tabular}

$\begin{array}{ll}\begin{array}{l}\text { Gandaki } \\ \text { Krishi }\end{array} & \text { Practices } \\ \text { Pokhara } & \text { Practices, news and notifications } \\ \text { Krishi } & \\ \text { Smart Kishan } & \text { Agri-commerce }\end{array}$

GeoKRISHI Practices, weather forecast, focused on location specific farming

Digo Krishi

Information about Conservation Agriculture-based Sustainable Intensification (CASI) technology and practices

Agri-tech Ne- For solving calculations related to pal

Developers

PPCR/AMIS

(Offered by Info Developers Pvt.Ltd)

Krishi Television and New IT Venture Corp.

Kapurkot Village 1,000 Municipality

ICT in Agriculture 1,000 Nepal

AAdhunik Krishi 1,000 Kishan Sansar

Offered By Dream- 1,000

Work Solution

krishinetworknepal $\quad 1,000$

Offered by Swift 500 Technology

Vegetable Crop Development Center, Khumaltar

Offered by DreamWork Solution

Offered by Prologic 100 Solutions

Dhankuta Munici- 100 plality

(Offered by SmartGov)

Gandakikrishi

(Offered by DreamWork Solution)

pokharakrishi

Pathibhara Tech- 100 nology

Pathway Technologies and Services Pvt. Ltd.

Digokrishi

AgritechNepal
Weblink

https://play.google.com/store/apps/details?id=np.com.rowsun. hamrokrishi

https://play.google.com/store/apps/details?id=com.tv.kishantv

https://play.google.com/store/apps/details?id=com. upasarga. .krishi

https://play.google.com/store/apps/details?id=com.krishi_ghar

https://play.google.com/store/apps/details?id=com.dwn. aadhunik.krishi

https://play.google.com/store/apps/details?id=com.tomato. Nepal

https://play.google.com/store/apps/details?id=com.BBT.kishan

https://play.google.com/store/apps/details?id=com.dws.vedc

https://play.google.com/store/apps/details?id=com. IntelliJ.IDE. OrganicNepal

https://play.google.com/store/apps/details? id=com . prologicsolutions . krishisewa

https://play.google.com/store/apps/details?id=com.upasarga. .dhankutakrishi

https://play.google.com/store/apps/details?id=com.dws.gandaki. krishi

https://play.google.com/store/apps/details?id=com.dws. pokhara. krishi

https://play.google.com/store/apps/details?id=com. pathibharatechnology.smartkishan

https://play.google.com/store/apps/details?id=com. pathway.geokrishi_farm

https://play.google.com/store/apps/details?id=com.dws.digokrishi.nepali

https://play.google.com/store/apps/details?id=com.agritech_nepal.com 
Table 2 | Agriculture news web sites in Nepal

\begin{tabular}{|c|c|c|c|}
\hline Name & Language & Format & Weblink \\
\hline krishionline & Nepali & Text, video & https://krishionline.com \\
\hline krishitelevision & Nepali & Text, Video & http://krishitelevision.com \\
\hline halokhabar & Nepali & Text, video & http://halokhabar.com \\
\hline krishakkhabar & Nepali & Text & http://krishakkhabar.com \\
\hline naturekhabar & English & Text & http://naturekhabar.com/en \\
\hline Bos Agriculture Nepal & Nepali & Video & https://www.youtube.com/c/BosagriculturetechnologyNepal \\
\hline krishakraprabidhi & Nepali & Text & https://krishakraprabidhi.com/ \\
\hline
\end{tabular}

The use of mobile phones in Nepal has undoubtedly been increasing in recent years, which lends them enormous potential as tools for agricultural information dissemination. In particular, a large number of different mobile applications (Table 1) have been developed in Nepal.

\section{Agri news sites}

A number of agriculture news sites is currently online. These sites provide recent news, notifications, and analytical perspectives in the agricultural sector, along with sharing success stories and farming knowledge.

\section{Social media and websites}

Social media platforms are increasingly being used by stakeholders in the context of agricultural extension for sharing news, notices and current developments. The current use of social media in Nepal has been helpful to express ideas, share information and make queries. Facebook pages and groups have been particularly widely used to communicate and share information. Social media has a strong potential to help facilitate interaction between extension agents and farmers. This social

Table 3 | Government of Nepal, Ministry of Agriculture and Livestock Development, Singhadurbar, Kathmandu, Nepal

$$
\begin{array}{ll}
\text { Website } & \text { https://www.moald.gov.np } \\
\text { Email } & \text { info@moald.gov.np } \\
\text { Twitter } & \text { https://www.twitter.com/Hello_MOALD } \\
\text { Facebook } & \text { https://www.fb.com/gunaso.moald }
\end{array}
$$

Agriculture and Information Training Center

$$
\text { Website https://www.aitc.gov.np }
$$

presence is however mainly beneficial to farmers with higher literacy.

All ministries of Nepal host websites, although their user-friendliness may need to be assessed. As of 2018, the Government of Nepal has also prepared initiatives for every government office to have its own twitter handle. ${ }^{[17]}$ Facebook pages also exist for many government offices.

\section{Agri-portals}

After Nepal was selected for the Pilot Program for Climate Resilience (PPCR) in 2009, the Building Resilience to Climate-Related Hazards (BRCH) project was designed as one of the five projects. The Agriculture Management Information System (AMIS) is one of the components of $\mathrm{BRCH}$, and has been developed to provide agro-advisory services.

The Nepal Seed and Fertilizer project (NSAF) is funded by the United States Agency for International Development (USAID), as part of the International Maize and Wheat Improvement Center (CIMMYT) project. CIMMYT has jointly worked with Nepal's Soil Management Directorate and the Nepal Agricultural Research Council (NARC) in developing the interactive digital soil map to document precise data about soil properties (accessible at https://nsafmap.github.io). ${ }^{[18]}$ Although helpful in providing scientists and academics with soil information, the application needs to be more farmerfriendly to achieve its goals among farmers.

The Digital Seed Information System (DSIS) will make registered seeds available, along with information on seed demand and supply, and will be completed as part of NSAF in 2020. The system is also intended to act as a seed portal and market information system to help Nepalese farmers select suitable varieties. ${ }^{[19]}$ 
Table 4 | Agri-portals in Nepal

Name

Government of Nepal Ministry of Agriculture and Livestock Development, PPCR: Building Resilience to Climate Related Hazards Project, Agriculture Management Information System

Soil Map

Table 5 | Agri-portals in Nepal

Name

NARC Online Library

E-pustakalaya
Weblink

http://namis.gov.np

https://nsafmap.github.io

\section{Online courses and MOOCs}

No online courses or MOOCs appear to have been developed specifically to facilitate learning in any agriculture topics. There is therefore a dire need to introduce sites like AgMOOCs in the country (following India's example). This requires collaboration at the university level and with other bodies working in uplifting agriculture. Online courses in general yet remain to be explored in the country, although there has been initial work from Kathmandu University (at http://mooc.ku.edu.np) in 2016, which was well-received by participants. ${ }^{[20]} A$ very valuable step has been the opening of Nepal Open University (https://nou.edu.np) in 2016, which has the potential to develop many online courses.

\section{Online libraries}

The two main online libraries available for browse ebooks, documents, journals, and articles in Nepal are the NARC online library and E-pustakalaya. Both sites have books related to agriculture topics. The websites of stakeholders may also provide additional access to ebooks.

\section{Discussion}

It has been suggested that availability of digital resources themselves is not the main factor for access to ICT, but rather that that physical, digital, human, and social resources need to be in place as a first step. ${ }^{[21]}$ Computers and internet are only the tools. Bridges.org lists a set of criteria that determine the effective reach of ICT: physical access, affordability, appropriateness,
Weblink

http://nkcs.org.np/narc/pmb/opac_css/index.php

https://pustakalaya.org/en/ relevancy, integration, human capacity, economic environment, legal frame, political support and public interest. ${ }^{[22]}$

Awareness of ICT is increased by the sharing and disseminating of information and by collaboration. ${ }^{[23]}$ The investigation of possible impacts of ICT on agriculture in Nepal still require further research to cover the multitude of possibilities inherent in e-extension. ${ }^{[9]} \mathrm{How}$ ever, proper adaptation, integration and development of ICT tools and initiatives on part of the government by lack of proper policies deters the progress of adoption of ICT. ${ }^{[24]}$ There is also a requirement to assess the effectivity criteria noted above, which should be incorporated and addressed. E-extension appears to be the prime candidate to improve and enhance the extension system currently in effect in Nepal.

The limitations of e-extension include effective applicability and accessibility. Affordability as well as low educational level and lack of interest on part of the farmers may impede further uptake. Improved strategic planning that specifically includes rural farmers may support the promotion of ICT approaches such as e-extension. ${ }^{[25]}$

Schedule 6 of the Constitution of Nepal (2015) has placed the area of "agriculture and livestock development" in the domain of the state. Similarly, the Local Governance Act (2017) assigns "agricultural extension" to the domain of municipalities. "Agriculture" remains in the concurrent domain of federation, state and local governments (Schedule 9). Overcoming the issues that remain will undoubtedly require improvement to the overall mechanisms at all tiers of the Nepalese government. Under current circumstances, local governance can avail itself of the same opportunities as other tiers of government for advancement and promotion of eextension. ${ }^{[26]}$ 
The benefits of e-extension are: ${ }^{[27]}$

1. Reductions in cost together with an ability to reach large audiences in limited time make e-extension an efficient approach.

2. Feedback mechanisms are rapid; interaction between experts and farmers is accelerated.

3. Visual presentation and the use of multimedia makes information easier to understand understandable and disseminate.

4. Public and private relationships can be enhanced; tenuous relations between farmers and extension institutions can be strengthened. Further possibilities for e-trading and e-learning exist.

5. Issues of finance and insurance become more accessible to farmers. Farmers' awareness of a variety of topics may be increased.

6. Opportunities to study and adopt specific farming methods become available. Local and global knowledge become easier to integrate.

Figure 1 presents a possible model for implementing eextension in Nepal. Government, private agencies and stake holders develop mobile applications, agriculture web portals, MOOCs and online courses, while increasing their presence on social media. The developed products have customized functions and objectives. Social media presence assists in receiving feedback and the sharing of information.

\section{Conclusions}

This paper aimed to provide an overview of e-extension in Nepal. As modern Nepal has entered into a federal system of government, the area of agriculture extension has seen the emergence of new topics and fields of discourse. Difficulties still exist in effectively aligning and directing connected extension, education and research. The development of e-extension will act as a bridging tool, assisting in the growth of agricultural development in Nepal. Innovation in e-extension can lead to greater resilience, adaptation and sustainability in the system. E-extension has improved extension processes in general and will continue to do so, and associated innovation can be expected to make positive impacts on Nepalese agriculture.

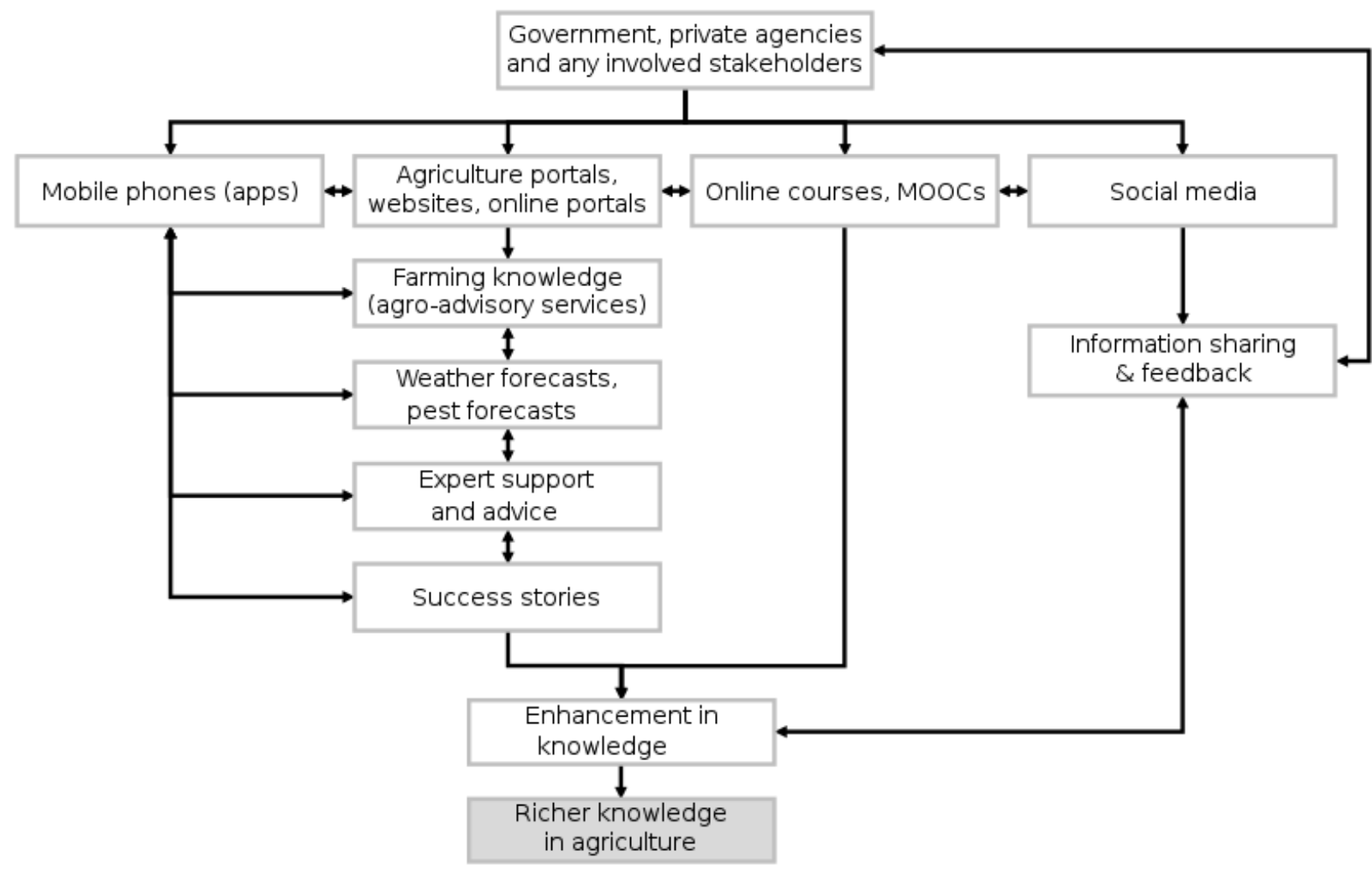

Figure 1 | A possible model for e-extension in Nepal 


\section{Additional information}

\section{Acknowledgements}

The author acknowledges reviewers and editors for constantly helping to improve the article.

\section{Competing interests}

The authors have no competing interest.

\section{Funding}

None

\section{References}

1. Agricultural Extension Services Delivery System in Nepal (PDF) (Report). Food and Agriculture Organization of the United Nations UN Complex, Pulchowk, Nepal. 2010. Retrieved 2020-08-08.

2. To, S (2018). Operation of Community Agriculture Extension Service Center and its Management (PDF) (Report). Global Sustainable Research and Development Center Pvt. Ltd. Tokha, Kathmandu-13.

3. Devkota, Ki Thapa, D; Dhungana, H (2016). "Weak institutional interaction: Reason for poor agricultural extension services delivery in Nepal". New Angle: Nepal Journal of Social Science and Public Policy 4 (1): 88-103. ISSN 2565-5124.

4. Kunwar, Laxman Singh (2017-07-07). "Emigration of Nepalese People and Its Impact". Economic Journal of Development Issues 19 (1-2): 77-82. doi:10.3126/ejdi.v19i1-2.17705. ISSN 2091-2285.

5. Parajulee, M (2017). Agricultural Education, Research, and Extension (PDF)(Report). NAPA Research/Policy Brief. RPB1. pp. 1-5.

6. Dhital, Pankaj Raj (2017-09-07). "Agricultural Extension in Nepal: Experiences and Issues". Journal of Advances in Agriculture 7 (3): 10711082. doi:10.24297/jaa.v7i3.6287. ISSN 2349-0837.

7. Afzal, Adeel; Al-Subaiee, Faisal Sultan; Mirza, Abdulrahman A. (2016-10). "The Attitudes of Agricultural Extension Workers towards the Use of EExtension for Ensuring Sustainability in the Kingdom of Saudi Arabia". Sustainability 8 (10): 980. doi:10.3390/su8100980. ISSN 2071-1050.

8. Philippine e-Extension Portal. e-extension.gov.ph (Report). Electronic Extension in Philippine Agriculture and Fisheries.

9. Paudel, R.; Baral, P.i Lamichhane, S.; Marahatta, B. P. (2018-12-03). "ICT Based Agro-Advisory Services in Nepal". Journal of the Institute of Agriculture and Animal Science 35 (1): 21-28. doi:10.3126/jiaas.v35i1.22510. ISSN 2091-0134

10. Rijal, S; Devkota, Y (2019-08-08). "Television for Agricultural Extension in Nepal". Acta Scientific Agriculture 3 (9): 45-47. doi:10.31080/asag.2019.03.0605. ISSN 2581-365X.

11. Nepal Telecommunications Authority (2019). MIS Report (PDF) (Report). 178. Nepal Telecommunications Authority.
12. 2019 Digital Nepal Framework: Unlocking Nepal's Growth Potential (PDF)(Report). Ministry of Communication and Information Technology. 2019.

13. Saravanan, Raj; Bhattacharjee, Suchiradipta (2014). "Mobile Phone Applications for Agricultural Extension in India". In Saravanan, Raj (ed.). Mobile Phones for Agricultural Extension: Worldwide mAgri Innovations and Promise for Future. New Delhi: New India Publishing Agency. pp. 175.

14. Vimala, D; Ravisankar, T (2012). "Fisher Friend Mobile Application-An Innovative and Promising ICT Tool in Fisheries e-Extension". Fishery Technology 49 (2): 199-203. ISSN 2277-9078.

15. Mahra, Girijesh Singh; Jirli, Basavaprabhu; Rai, Ashok (2013). "M-learning: An Educational Approach for Change in Hills of Uttarakhand". Journal of Global Communication 6 (2): 144. doi:10.5958/j.0976-2442.6.2.021. ISSN 0974-0600.

16. Singh, Akanchha; Jirli, Basavaprabhu (2019). "Changing Perception and Awareness towards ICT along with Changing Roles of Stakeholders in Agriculture". Research Journal of Agricultural Sciences 9 (6): 1412-1416. ISSN 0976-1675.

17. "Govt agencies required to use social media". The Himalayan Times. 201808-20.

18. "New digital maps to support soil fertility management in Nepal". CIMMYT. 2018-12-04

19. "Seed systems in Nepal are going digital". CIMMYT. 2020-01-06.

20. Shakya, Manoj; Shrestha, Sushil; Manandhar, Rajesh; Joshi, Manish; Khanal, Prasamsa (2017-07-12). "Reflections on First MOOC of Nepal: From Learner's Perspectives". Conference: International Conference on Open and Innovative Education (Hong Kong).

21. Dowding, Martin R. (2004). "Technology and Social Inclusion: Rethinking the Digital Divide". Canadian Journal of Communication 29 (1). doi:10.22230/cjc.2004v29n1a1415. ISSN 1499-6642.

22. The Real Access / Real Impact framework for improving the way that ICT is used in development (PDF) (Report). bridges.org. 2005.

23. Singh, Akanchha; Jirli, Basavaprabhu; Sinha, Aditya (2019-10-17). "ICT Revolution in Agriculture: A Boon for Farmers". In Ghadei, Kalyan (ed.). Compendium on agricultural extension. New Delhi. pp. 363-372. ISBN 97881-7622-372-0. OCLC 953344798.

24. Sharma, Manoj; Kaur, Gagandeep; Gill, M (2012-07-10). "Use of Information and Communication Technology in Agriculture by Farmers of District Kapurthala". Journal of Krishi Vigyan 1 (1): 83-89. ISSN 2349-4433.

25. Richardson, Don (2006). "ICTs: transforming agricultural extension?". Report of the 6th Consultative Expert Meeting of CTA's Observatory on ICTs (Report). The ACP-EU Technical Centre for Agricultural and Rural Cooperation.

26. Kyle, Jordan; Resnick, Danielle (2016). Nepal's 2072 Federal Constitution: Implications for the Governance of the Agricultural Sector. www.ifpri.org (Report). The International Food Policy Research Institute (Development Strategy and Governance Division). Retrieved 2020-09-08.

27. Bhattacharyya, Tapas; Patil, Vinayak; Bhave, S.; A., Sawant; Haldankar, Parag; Narkhede, Satish (2018-05-10). "e-Extension Services of SAUs in Indian Agriculture: Challenges and Management Strategies". Advanced Agricultural Research and Technology Journal 2 (2): 119-125. ISSN 25813749 . 